\title{
GENETIC CONTROL OF YIELD AND YIELD RELATED TRAITS IN SELECTED UPLAND COTTON VARIETIES OF PAKISTAN
}

\author{
Syed Awais Sajid Shah', Lal Hussain Akhtar', Rashid Minhas ${ }^{1}$, Muhammad Shahjahan \\ Bukhari $^{1}$, Syed Sajid Masood Shah ${ }^{2}$ and Faqir Muhammad Azhar ${ }^{3}$
}

\begin{abstract}
Inheritance pattern of some polygenic characters were studied in $5 \times 5 F_{1}$ diallel hybrids and their parents of upland cotton. $20 F_{1}$ hybrids and their parents were grown in field under randomized complete block design at experimental area of the Department of Plant Breeding and Genetics, University of Agriculture, Faisalabad. Diallel analysis was used to determine the mode of gene action and genetic components for various yield related traits like plant height, monopodial branches plant ${ }^{-1}$, sympodial branches plant ${ }^{-1}$, bolls plant ${ }^{-1}$, boll weight and seed cotton yield plant ${ }^{-1}$. Results of regression coefficients showed that all the characters were fit for genetic analysis. Additive type of gene action with partial dominance and over dominance were involved for the expression of the traits studied. Results suggested that these characters can be improved through appropriate selection method or by hybrid development.
\end{abstract}

Keywords: Diallel analysis, Inheritance, seed cotton yield, Gossypium hirsutum

\section{INTRODUCTION}

Cotton (Gossypium hirsutum L.) proved to be an important fiber and cash crop in many countries such as USA, China, India, Pakistan, Uzbekistan, Australia and Africa. Cotton crop is mainly cultivated for its fibre (Ashokkumar et al., 2010). Cotton having great economic importance for Pakistan as it plays a important role in agriculture, industrial development, decrease of unemployment and earning of foreign exchange through export of its raw material and its finished products. This crop also having a vital role in our textile industry as it provides basic raw material to its growth. Cotton seed is an important source of edible oil and contributes 60 to $70 \%$ to the local edible oil production (Khan, 2003; Ahmad et al., 2006; Minhas et al., 2008). Low grade oil is being used in soap and lubricant manufacturing. Residual seed cake is a valuable proteinacious food and is used in livestock feed.
For increasing cotton production many efforts are being made. Keen interest is the most important factor in production process. Many genetic manipulations and breeding practices have been used by the cotton breeders for evolving high yielding cultivars with better fiber quality. For this attempt, use of crossing technique and variation in crop with great observation is of deep importance in a breeding programme (Ali et al., 2009).

Diallel analysis technique by Hayman (1954) and Jinks (1954) is a useful method to obtain accurate information about the type of gene action and inheritance pattern of various polygenic traits of economic importance. Diallel analyses has been widely used by many breeders and go through to a comprehensive study of diallel assumptions, genetic mechanism and genetic components of variance which adjust the plant variables 
in various populations under different environmental conditions (Khan et al., 2007; Khan and Hassan, 2011). Genetic components of variation and heritability are also estimated from diallel analysis which is useful for the selection of perfect parents and breeding technique. The present research work was conducted to obtain genetic information and inheritance pattern of various yield and fiber quality plant traits. This type of information may help the cotton breeders to formulate a breeding programme for cotton improvement successfully.

\section{MATERIALS AND METHODS}

The experimental material consisting of five parental genotypes of upland cotton namely Stoneville-701, NIAB Krishma, LA-85-521, Acala-63-75 and Bt-196 showing a range of yield and fiber quality traits, were sown in earthen pots placed in glasshouse. During germination and growth, environmental conditions were possibly controlled and recommended agronomic practices were adopted. In glasshouse, the temperature was maintained at $35-40^{\circ} \mathrm{C}$ throughout the growth period. At flowering, the parental lines were crossed in a complete diallel fashion $(5 \times 5)$ to generate $20 \mathrm{~F}_{1}$ crosses (including reciprocals) along with five selfs.

The $\mathrm{F}_{0}$ seed from all the crosses along with their parents was sown in the field during the month of June at experimental area of the department of Plant breeding and Genetics, University of Agriculture, Faisalabad, following triplicated randomized complete block design. Nine seeds of each cross were sown per row with a distance of $30 \mathrm{~cm}$ and $75 \mathrm{~cm}$ within and between rows, respectively. All recommended agronomic practices and crop protection measures were carried out. At maturity, data on plant height $(\mathrm{cm})$, monopodial branches plant $^{-1}$, sympodial branches plant ${ }^{-1}$, bolls plant $^{-1}$, boll weight $(\mathrm{g})$ and seed cotton yield plant $^{-1}(\mathrm{~g})$ were recorded from seven guarded plants on individual plant basis. For analyzing the data for genetic interpretation following Hayman-Jinks model, it was necessary to observe whether genotypic differences for the above mentioned traits are significant or not (Steel et al., 1997). To test the perfectness of the data for additive-dominance model, a scaling test i.e. joint regression analysis was carried out. According to Hayman (1954) and Jink (1954), the regression coefficient must deviate significantly from zero but not from unity for the data to be adequate for additivedominance model. This information on gene action was obtained by plotting the covariance (Wr) of each array against its variance ( $\mathrm{Vr}$ ). Therefore the data of $20 \mathrm{~F}_{1}$ hybrids and their parents were subjected to analysis of variance technique. From the diallel data variances of each array (Vr), covariances (Wr), variance of parental means $\left(\mathrm{V}_{0} \mathrm{~L}_{0}\right)$, variance of array means $\left(\mathrm{V}_{0} \mathrm{~L}_{1}\right)$, means of array variances $\left(\mathrm{V}_{1} \mathrm{~L}_{1}\right)$ and mean array covariances $\left(\mathrm{W}_{0} \mathrm{~L}_{0}\right)$ were calculated.

\section{RESULTS AND DISCUSSIONS}

In order to see the validity of the data for analysis following simple additive-dominance model data were then subjected to joint regression analysis. For this purpose the mean values of each cross and five parents were arranged into diallel tables. According to Hayman (1954) and Jinks (1954), the data to be adequate for analysis the regression coefficient (b) value must deviate significantly from zero but not from unity and this is possible only if all the points concerned with the simple additivedominance model are fulfilled. Results of joint regression analysis are showed in Table 01. All of them are deviated significantly from zero but not from unity and therefore the data for all the above traits were found perfect for genetic analysis. 
Table 01: Joint regression coefficient of six plant traits of G. hirsutum L.

\begin{tabular}{lc}
\hline \multicolumn{1}{c}{ Character } & Regression coefficient \\
\hline Plant height & $0.78 \pm 0.15$ \\
Number of monopodial branches & $0.97 \pm 0.13$ \\
Number of sympodial branches & $1.01 \pm 0.14$ \\
Number of bolls & $0.79 \pm 0.17$ \\
Boll weight & $1.04 \pm 0.07$ \\
Seed cotton yield & $0.88 \pm 0.15$ \\
\hline
\end{tabular}

\section{Plant height}

Genetic components of variation for plant height are presented in Table 02. Additive component D (91.71) was significant and higher than non-additive components. $\mathrm{H}_{1}$ (11.34) and $\mathrm{H}_{2}$ (15.88) showed that plant height was controlled by additive gene effects. Average degree of dominance $\left(\mathrm{H}_{1} / \mathrm{D}\right)^{0.5}$ i.e. 0.35 indicated the presence of partial dominance in the genetic control of the character and this was confirmed by the position of regression line on $\mathrm{Vr} / \mathrm{Wr}$ graph (Figure 01a). The differences in $\mathrm{H}_{1}$ (11.34) and $\mathrm{H}_{2}$ (15.88) signified unequal distribution of dominant and recessive genes in the parents for this character which also verified by the ratio of $\mathrm{H}_{2} / 4 \mathrm{H}_{1}(0.35)$ which was more than the maximum value of 0.25 . The negative value of $\mathrm{F}$ indicated that the frequency of dominant alleles was lower than the frequency of recessive alleles. The estimate of the ratio $\left(4 \mathrm{DH}_{1}\right)^{0.5}+\mathrm{F} /\left(4 \mathrm{DH}_{1}\right)^{0.5}-\mathrm{F}$ (0.55) also supported the presence of partial dominance for said character. The negative value of $h^{2}(-2.63)$ suggested the trend of dominance towards lower parent as shown in graph (Figure 1a). The significant value of the environmental component of variance $\mathrm{E}$ (11.74) depicted that the environment played important role in the phenotypic expression of this trait. Narrow sense heritability estimated was moderate $(61 \%)$.

Epistasis was found to be absent as the regression line did not deviate significantly from unit slope (b). From the distribution of cultivar positions on the regression line, it was

revealed that NIAB Krishma being closer to the point of origin had maximum dominant genes and Acala-63-75 being away from origin possessed most of the recessive genes.

\section{Monopodial branches}

Estimates of genetic components of variation for monopodial branches per plant revealed that $\mathrm{D}(0.70)$ was higher than the $\mathrm{H}_{1}(0.14)$ and $\mathrm{H}_{2}(0.12)$ signifying the importance of genes acting cumulatively (Table 02 ). The degree of dominance $\left(\mathrm{H}_{1} / \mathrm{D}\right)^{0.5}$ i.e., 0.45 was partial as it was less than 1 and this was confirmed by the position of regression line on the $\mathrm{Vr} / \mathrm{Wr}$ graph (Figure 01b). Difference of $\mathrm{H}_{1}(0.14)$ and $\mathrm{H}_{2}$ $(0.12)$ is an indication of unequal distribution of dominant and recessive genes in the parents. This was verified by the ratio of $\mathrm{H}_{2} / 4 \mathrm{H}_{1}(0.21)$ which was less than its maximum value $(0.25)$. The positive value of $F(0.10)$ indicated that the frequency of dominant alleles was higher than recessive alleles. The ratio of $\left(4 \mathrm{DH}_{1}\right)^{0.5}+\mathrm{F} /$ $\left(4 \mathrm{DH}_{1}\right)^{0.5}-\mathrm{F}(1.39)$ also supported the presence of partial dominance type of inheritance for this character. The negative value of $h^{\wedge}-0.001$ suggested the trend of dominance towards lower parent i.e. the parent coming near the point of origin in graph. The non significant value of environmental component of variance E 0.02 depicted that the environment played a little role in the phenotypic expression of this trait. Narrow sense heritability estimated was much high (94\%). 
Table 02: Variations in genetic components for plant height, monopodial and sympodial branches, number of bolls, boll weight and seed cotton yield.

\begin{tabular}{|c|c|c|c|c|c|c|}
\hline \multirow[b]{2}{*}{ Genetic components } & \multicolumn{6}{|c|}{ Estimates } \\
\hline & $\begin{array}{l}\text { Plant } \\
\text { height }\end{array}$ & $\begin{array}{c}\text { Monopodial } \\
\text { branches }\end{array}$ & $\begin{array}{l}\text { Sympodial } \\
\text { branches }\end{array}$ & $\begin{array}{l}\text { Number of } \\
\text { bolls plant }^{-1}\end{array}$ & $\begin{array}{c}\text { Boll } \\
\text { weight }\end{array}$ & $\begin{array}{l}\text { Seed cotton } \\
\text { yield }\end{array}$ \\
\hline $\mathrm{D}$ & $91.71^{*} \pm 4.1$ & $0.70^{*} \pm 0.0$ & $27.06^{*} \pm 0.6$ & $31.09^{*} \pm 2.1$ & $0.26^{*} \pm 0.00$ & $214.94^{*} \pm 12.9$ \\
\hline $\mathrm{H}_{1}$ & $11.34^{\mathrm{ns}} \pm 11.30$ & $0.14^{*} \pm 0.1$ & $0.73^{\mathrm{ns}} \pm 1.6$ & $7.44^{\mathrm{ns}} \pm 5.4$ & $-0.010^{\mathrm{ns}} \pm 0.01$ & $32.33^{\mathrm{ns}} \pm 34.8$ \\
\hline $\mathrm{H}_{2}$ & $15.88^{\mathrm{ns}} \pm 10.3$ & $0.12^{*} \pm 0.1$ & $0.76^{\mathrm{ns}} \pm 1.4$ & $6.63^{\mathrm{ns}_{\mathrm{s}}} \pm 4.9$ & $-0.006^{\mathrm{n}} \pm 0.01$ & $20.23^{\mathrm{ns}} \pm 31.6$ \\
\hline $\mathrm{F}^{2}$ & $-18.62^{\text {ns }} \pm 10.5$ & $0.10^{\mathrm{ns}} \pm 10.0$ & $7.72^{*} \pm 1.4$ & $-10.211^{\mathrm{ns}}+5.0$ & $-0.027^{\mathrm{ns}} \pm 0.01$ & $-123.84^{\mathrm{ns}} \pm 32.2$ \\
\hline$h^{\wedge}{ }^{2}$ & $-2.63^{\text {ns }} \pm 6.9$ & $-0.001^{\mathrm{ns}} \pm 0.0$ & $0.29^{\mathrm{ns}} \pm 0.9$ & $-0.14^{\mathrm{ns}} \pm 3.3$ & $-0.005^{\mathrm{ns}} \pm 0.0$ & $17.28^{\mathrm{ns}} \pm 21.3$ \\
\hline $\mathrm{E}$ & $11.74^{*} \pm 1.7$ & $0.02^{\mathrm{ns}} \pm 0.0$ & $1.95^{*} \pm 0.2$ & $1.81^{*} \pm 0.8$ & $0.49^{\mathrm{ns}} \pm 0.0$ & $17.28^{*} \pm 5.3$ \\
\hline$\left(\mathrm{H}_{1} / \mathrm{D}\right)^{0.5}$ & 0.35 & 0.45 & 0.16 & 0.49 & 0.19 & 0.39 \\
\hline $\mathrm{H}_{2} / 4 \mathrm{H}_{1}$ & 0.35 & 0.21 & 0.26 & 0.22 & 0.15 & 0.16 \\
\hline$\left(4 \mathrm{DH}_{1}\right)^{0.5}+\mathrm{F} /\left(4 \mathrm{DH}_{1}\right)^{0.5}-\mathrm{F}$ & 0.55 & 1.39 & 14.30 & 0.50 & 0.58 & 0.15 \\
\hline $\mathrm{h}_{(\mathrm{ns})}^{2}$ & 0.61 & 0.94 & 0.87 & 0.69 & 0.81 & 0.61 \\
\hline
\end{tabular}

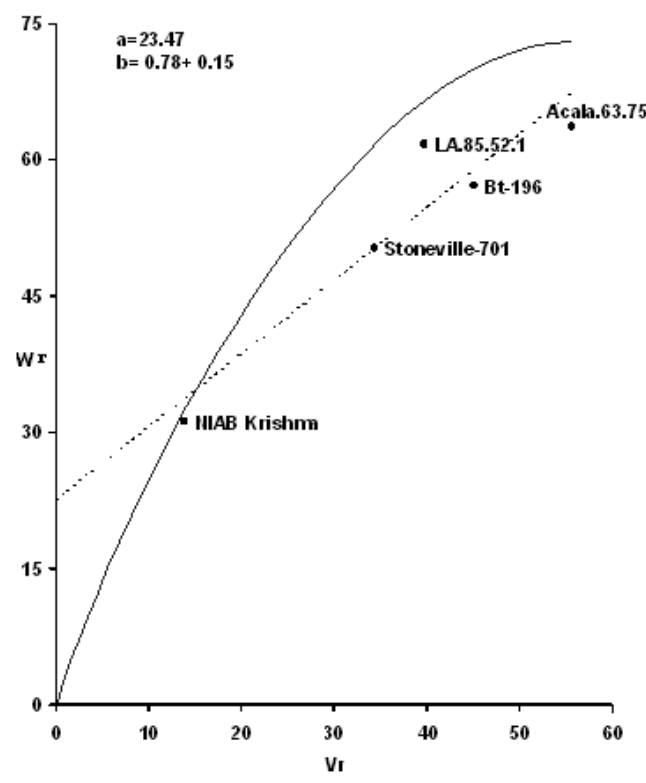

Figure 1a: Vr/Wr graph for plant height

The unit slope of regression line revealed that non allelic interaction was absent. The distribution of cultivar positions on the regression line showed that Stoneville-701 being closer to the point of origin had maximum number of dominant genes and Bt-196 being away from the point of origin possessed maximum recessive genes.

\section{Sympodial branches}

Comparison of the estimates of genetic components of variation for sympodial

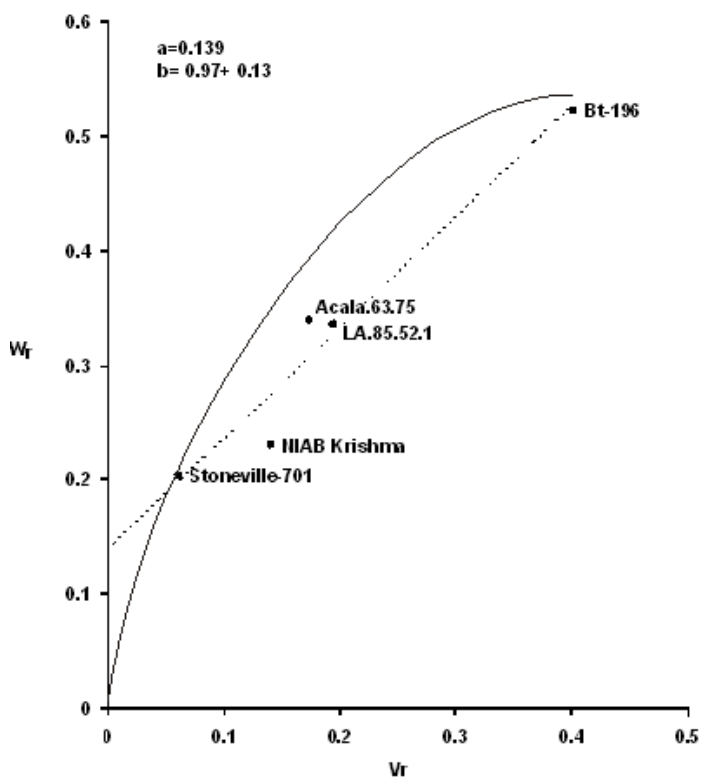

Figure 1b: Vr/Wr graph for monopodial branches

branches plant $^{-1}$ indicated that magnitude of additive component D (27.06) was higher and significant than non- additive components $\mathrm{H}_{1}$ (0.73) and $H_{2}(0.76)$ showing the predominant role of additive genes in the inheritance (Table 02). The degree of dominance $\mathrm{H}_{1} / \mathrm{D}^{0.5}(0.16)$ indicated the involvement of partial dominance which was also confirmed by the position of regression line on $\mathrm{Vr} / \mathrm{Wr}$ graph (Figure 1c). The difference in the values $\mathrm{H}_{1}(0.73)$ and $\mathrm{H}_{2}$ (0.76) demonstrated unequal distribution of dominant and recessive genes in the parents 
for this character which is verified by $\mathrm{H}_{2} / 4 \mathrm{H}_{1}$ (0.26) which was more than its maximum value of 0.25 . The positive value of $F(7.72)$ indicated that the frequency of dominant alleles was higher than recessive alleles. Estimate of ratio $\left(4 \mathrm{DH}_{1}\right)^{0.5}+\mathrm{F} /\left(4 \mathrm{DH}_{1}\right)^{0.5}-\mathrm{F}(14.30)$ also supported the presence of partial dominance type of inheritance. The positive value of $h^{\wedge 2}$ 0.29 suggested the trend of dominance towards higher parent i.e. the parent shown at the top in graph. The significant value of environment component of variance (1.95) depicted that environment played significant role in the phenotypic expression of the character. Estimate of narrow sense heritability was high i.e. $87 \%$.

Epistasis was absent as the regression line did not deviate significantly from unit slope (b). From the cultivar positions on the regression line, it was observed that Stoneville-701 being closer to the point of origin had maximum number of dominant genes and NIAB Krishma being away from the point of origin possessed most of the recessive ones.

\section{Number of bolls}

Estimates of genetic components of variation for bolls per plant are presented in Table 02 .

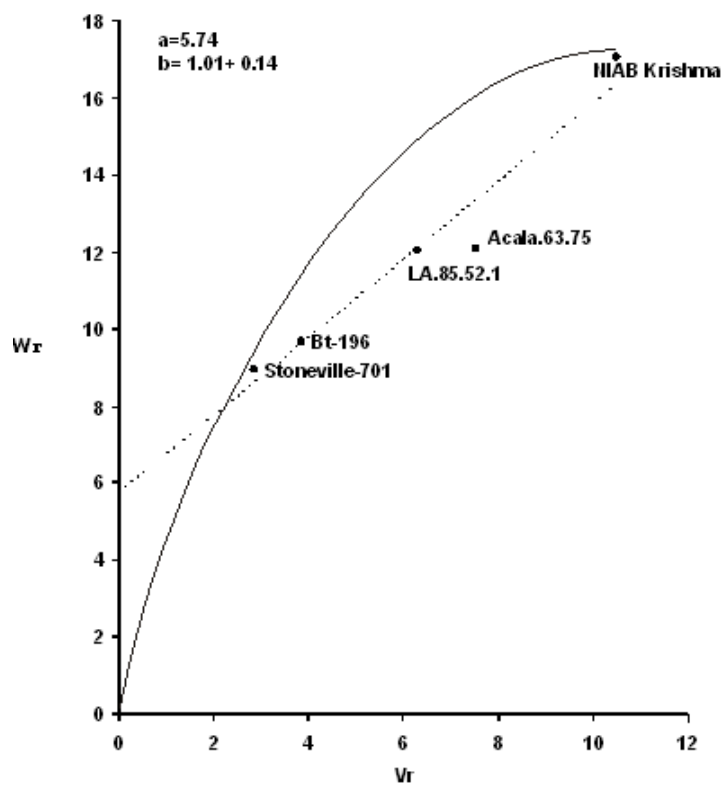

Figure 1c: Vr/Wr graph for sympodial branches
The magnitude of additive component of variance D (31.29) was significant and higher than non- additive components $\mathrm{H}_{1}(7.44)$ and $\mathrm{H}_{2}$ (6.63). This showed predominant role of additive genes in the inheritance of this character. The degree of dominance $\mathrm{H}_{1} / \mathrm{D}$ (0.49) indicated the involvement of partial dominance. The difference of the values of $\mathrm{H}_{1}$ (7.44) and $\mathrm{H}_{2}$ (6.63) demonstrated unequal distribution of dominant and recessive genes in the parental lines which also verified by ratio of $\mathrm{H}_{2} / 4 \mathrm{H}_{1}(0.22)$ being less than its maximum value (0.25) (Figure 01d). The negative value of $F(-10.21)$ indicated that the frequency of dominant alleles was lower than recessive alleles. The ratio of $\left(4 \mathrm{DH}_{1}\right)^{0.5}+\mathrm{F} /\left(4 \mathrm{DH}_{1}\right)^{0.5}-\mathrm{F}$ (0.50) also supported the presence of partial dominance type of inheritance. The negative value of $h^{\wedge}(-0.14)$ suggested the trend of dominance towards lower parent i.e. the parent coming near the point of origin in graph. The significant value of environment component of variance (1.81) depicted that environment played significant role in the phenotypic expression of the character. Estimate of narrow sense heritability was moderate i.e. $69 \%$.

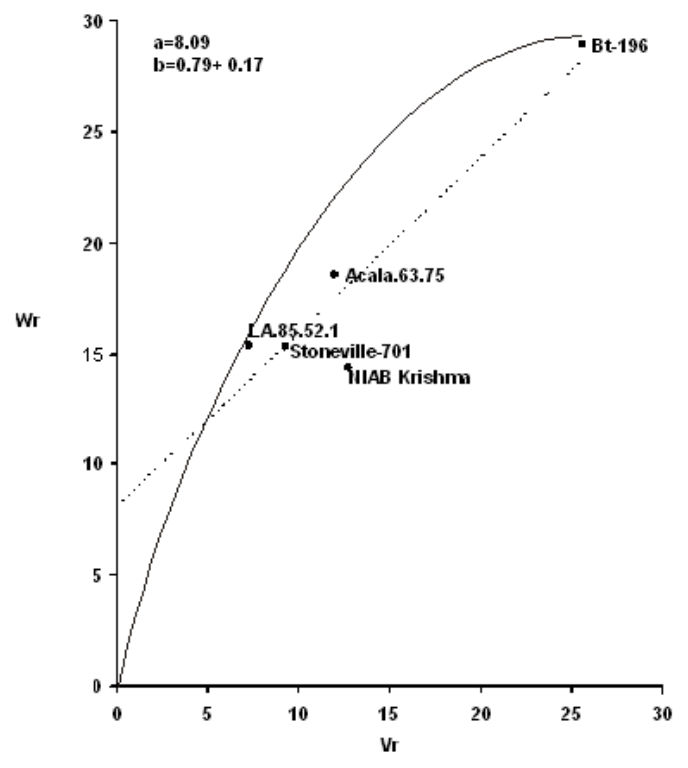

Figure 1c: Vr/Wr graph for bollsper plant 
Epistasis was absent as the regression line did not deviate from unit slope. The distribution of array points on the regression line indicated that the cultivars LA-85-52-1, Stoneville-701 and NIAB-Krishma being closest to the point of origin possessed maximum dominant genes while the cultivar Bt-196 being farthest from the point of origin possessed maximum recessive genes.

\section{Boll weight}

The magnitude of additive component $\mathrm{D}(0.26)$ was significant and higher than non-additive components, $\left\{\mathrm{H}_{1}(-0.010), \mathrm{H}_{2}(-0.006)\right\}$ which showed predominant role of additive genes in the inheritance of said trait. The degree of dominance $\mathrm{H}_{1} / \mathrm{D}(0.19)$ indicated the involvement of partial dominance for boll weight (Table 02). The difference of the values $\mathrm{H}_{1}(-0.010)$ and $\mathrm{H}_{2}(-0.006)$ demonstrated unequal distribution of dominant and recessive alleles which also verified by $\mathrm{H}_{2} / 4 \mathrm{H}_{1}(0.15)$ which was less than its maximum value of 0.25 .

The negative value of $F(-0.03)$ indicated that frequency of dominant alleles was lower than recessive alleles. The data presented in Figure 1e showed that additive type of gene action with partial dominance controlled the inheritance pattern of this trait as the regression line intercepted the Wr-axis above the point of origin. The ratio of $\left(4 \mathrm{DH}_{1}\right)^{0.5}+\mathrm{F} /$ $\left(4 \mathrm{DH}_{1}\right)^{0.5}-\mathrm{F}(0.58)$ also supported the presence of partial dominance type of inheritance. The negative value of $h^{\wedge 2}-0.005$ suggested the trend of dominance towards lower parent i.e. the parent coming near the point of origin in graph. The significant value of environmental component (0.01) depicted that environment played significant role in the phenotypic manifestation of the trait. Estimate of narrow sense heritability was high i.e. $81 \%$.
Epistasis was absent as the regression line did not deviate significantly from unit slope. From the distribution of cultivar position on the regression line, it was observed that genotype LA-85-52-1 being closest to the point of origin possessed maximum number of dominant genes while the cultivar NIAB Krishma being farthest to the point of origin possessed maximum number of recessive genes.

\section{Seed cotton yield}

The magnitude of additive component of variation D (214.94) was significantly higher than non-additive components. The $\mathrm{H}_{1}$ (32.33) and $\mathrm{H}_{2}$ (20.22) showed predominant role of additive genes in the inheritance of this character. The dominance ratio $\mathrm{H}_{1} / \mathrm{D}(0.39)$ indicated the presence of partial dominance in the genetic control and this was also confirmed by the position of regression line on $\mathrm{Vr} / \mathrm{Wr}$ graph (Figure 01f).

The differences in values of $\mathrm{H}_{1}$ (32.33) and $\mathrm{H}_{2}$ (20.22) signified unequal distribution of dominant and recessive genes in the parents which also verified by the ratio of $\mathrm{H}_{2} / 4 \mathrm{H}_{1}(0.16)$ being less than its maximum value $(0.25)$. The negative value of $F(-123)$ indicated that the frequency of dominant alleles was lower than recessive alleles. The ratio of $\left(4 \mathrm{DH}_{1}\right)^{0.5}+\mathrm{F} /$ $\left(4 \mathrm{DH}_{1}\right)^{0.5}-\mathrm{F}(0.15)$ also supported the presence of partial dominance type of inheritance for said trait. The positive value of $h^{\wedge}$ (17.28) suggested the trend of dominance towards higher parent i.e. the parent shown at the top in graph. The significant value of environment component of variance (17.28) depicted that environment played significant role in the phenotypic expression of this character. Narrow sense heritability was estimated to be high i.e. $61 \%$. 


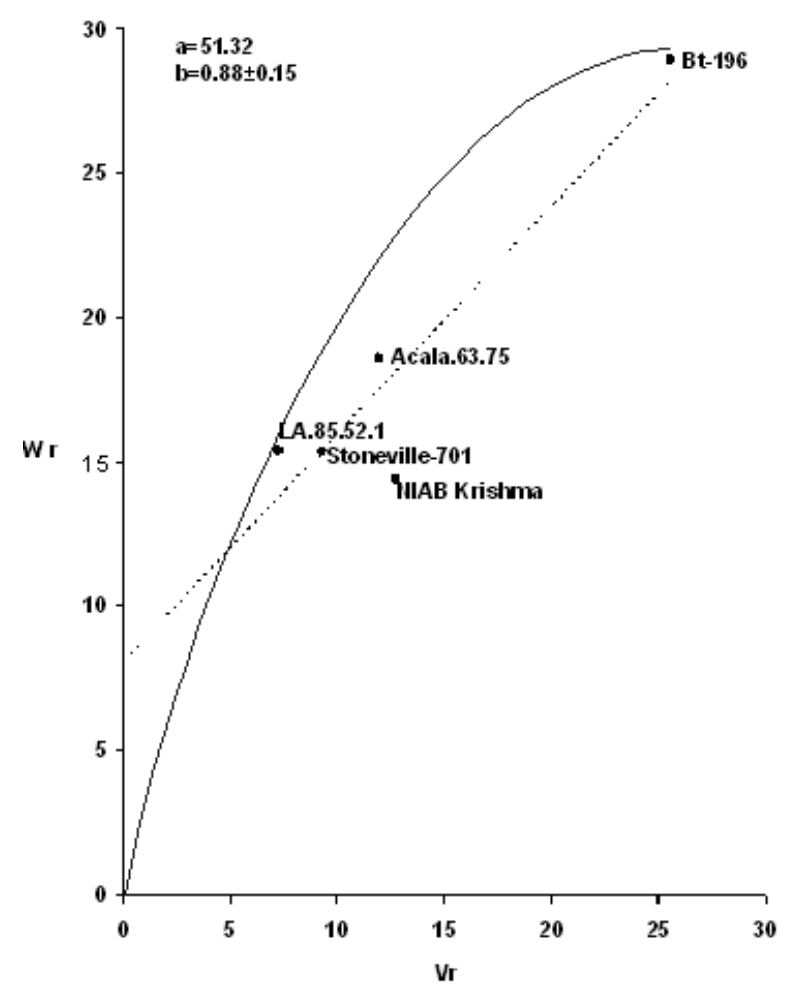

Figure 1f: Vr/Wr graph for seed cotton yield

Epistasis was absent as the regression line did not deviate significantly from unit slope (b). From the distribution of cultivar positions on regression line, it was revealed that cultivars LA-85-52-1, Stoneville-701 and NIAB Krishma being closest to the point of origin possessed the maximum number of dominant genes while Bt-196 being away from the point of origin possessed maximum number of recessive genes.

The present research work was carried out to study genetic mechanisms controlling plant height, monopodial and sympodial branches, bolls per plant, boll weight and seed cotton yield. The data represented that variations do exist for all these characters in the plant material examined i.e. the cultivars vary for various traits. This plant material may be used preferably by the research worker subject to the availability of knowledge on the genetic mechanism controlling variation which suggests that the following methods can be used for the analysis of data to move forward in breeding programme. For this purpose, triple test cross (Kearsey and Jinks, 1968), path coefficient analysis (Dewey and Lu, 1959), line $\mathrm{x}$ tester analysis (Kempthorne, 1957), generation mean analysis (Mather and Jinks, 1982) and North Carolina Designs (Comstock and Robinson, 1952), provide useful information on the pattern of inheritance, but diallel cross method (Hayman, 1954; Jinks, 1954; Griffing, 1956) has advantage to provide such information in $\mathrm{F}_{1}$ generation.

Increase in seed cotton yield is the priority given objective of cotton breeder, and due to interaction of many factors, it seems to be a complex character. Significant variation increases possibility of selection and in having a good crop cultivar (Ahmad et al., 2005). In the present study, additive variation was noted for seed cotton yield with varying degree of dominance. The work of Islam et al. (2001) and Abbas et al. (2008) supported the present observations whereas Haq and Azhar (2005) opposed this opinion and reported non-additive genetic effects for seed cotton yield. In the present study, the narrow sense 
heritability for seed cotton yield has been estimated to be median i.e. $61 \%$ in contrast to (Carvalho et al., 1995), who reported less heritability (19\%) for this trait and difference in observation may be due to the fact that yield of cotton, like in other crops it is the result of interaction between different components of yield and the environmental conditions.

Various yield components are responsible for seed cotton yield, either directly or indirectly, e.g., plant height, monopodial and sympodial branches considered to be indirect contributors to seed cotton yield (Azhar et al., 2004) whilst bolls per plant and boll weight are direct contributing traits to seed cotton yield (Subhan et al., 2002). In the present study, plant height was controlled by additive gene action with partial dominance, and similar genes, for this trait were reported by Ahmad et al. (2005), Iqbal et al. (2005) and Murtaza et al. (2006), whilst this differed from Muhktar et al. (2000) and Haq and Azhar (2005). The monopodial and sympodial branches were also controlled by the genes with additive properties with partial dominance. Abbas et al. (2008), Ali et al. (2009) and Ali and Khan (2007) were in great agreement with the present findings, whilst the findings of Kiani et al. (2007) revealed over dominance for these traits. Due to higher heritability estimates for plant height (61\%), monopodial branches (94\%) and sympodial branches $(87 \%)$, selection for these traits seems to be easy for the improvement of these traits.

The bolls per plant and boll weight were controlled by the genes with aggregate

\section{REFERENCES}

Abbas, A., Ali, M. A. and Khan, T.M. (2008). Studies on gene effects of seed cotton yield and its attributes in five American cotton cultivars, Pakistan Journal of Agriculture \& Social Sciences, 04(4): 147-152. 
Ahmad, R.T., Khan, I.A. and Zubair, M. (1997). Diallel analysis for seed cotton yield and its contributing traits in upland cotton, Indian Journal of Agricultural Sciences, 67(12): 583584 .

Ahmad, R. D., Malik, A. J., Hassan, G. and Khan, M. U. (2005). Genetic architecture of some quantitative traits of cotton (G. hirsutum L.), Gomal University Journal of Research, 21: $55-57$.

Ahmad, H. M., Kandhro, M. M., Laghari, S. and Abro, S. (2006). Heritability and genetic advance as selection indicators for improvement in cotton ( G.hirsutum L.), Journal of Biological Sciences, 6 (1): 96-99.

Ali, M. A. and Khan, I. A. (2007). Assessment of genetic variation and inheritance mode of some metric traits in cotton (G. hirsutum L.). Journal of Agriculture \& Social Sciences, 3(4): 112-116.

Ali, M. A., Abbas, A., Younas, M., Khan, T. M. and Hassan, H. M. (2009). Genetic bases of some quantitative traits in upland cotton (G. hirsutum L.), Journal of Plant Omics, 2(2): 91-97.

Ashokkumar, K., Ravikesavan, R. and Prince, K. S. J. (2010). Combining ability estimates for yield and fibre quality traits in line $\mathrm{x}$ tester crosses of upland cotton (G. hirsutum), International Journal of Biological Sciences, 2(1): 179-183.

Azhar, F.M., Naveed, M. and Ali, A. (2004). Correlation analysis of seed cotton yield with fiber characteristics in G. hirsutum L, International Journal of Agriculture \& Social Sciences, 06(4): 656-658.

Carvalho, L. P., Cruz, C. D. and Moraes, C. F. (1995). Diallel analysis of yield and other traits in cotton. Brazil Journal of Genetics, 18(1): 93-97.

Comstock, R. E. and Robinson, H. F. (1952). Estimation of average dominance of genes. In Gowen, J.w. Heterosis. Iowa State College Press, Ames, Iowa, p.p. 494-516.

Dewey, J.R. and Lu, K. H. (1959). A correlation and path coefficient analysis of components of crested wheat grass seed production, Agronomy Journal, 51: 515-518.

Griffing, B. (1956). Concept of general and specific combining ability in relation to diallel crossing systems, Australian Journal of Biological Sciences, 9: 463-493.

Haq, I. U. and Azhar, F. M. (2005). Genetic analysis of some fibre quality characters in $G$. hirsutum L., International Journal of Agriculture \& Biology, 7(2): 266-268.

Hayman, B. I. (1954). The analysis of variance of diallel crosses. Biometrics, 10: 235-245.

Iqbal, M., Khan, R. S. K., Hayat, K. and Khan, N. I. (2005). Genetic variation and combining ability for yield and fibre traits among cotton $\mathrm{F}_{1}$ hybrid population, Journal of Biological Sciences, 5(6): 713-716.

Islam, Z. U., Sadaqat, H. A. and Khan, F. A. (2001). Combining ability of some hirsutum cotton types for economic traits, International Journal of Agriculture \& Biology, 3(4): 411-412. 
Jinks, J. L. (1954). The analysis of continuous variation in a diallel cross of Nicotiana rustica varieties, Genetics, 39: 767-788.

Kearsey, M. J. and Jinks, J. L. (1968). A general method of detecting additive dominance and epistatic variation for a material trait, I.Theory. Heredity, 23: 403-409.

Kempthorne, O. (1957). An Introduction to Genetic Statistics. Wiley, New York. Pp-545.

Khan, M. A., Soomro, Z. A. and Leghari, N. (2003). Diallel analysis for yield and yield contributing characters in G. hirsutum L, Journal of Applied Sciences, 3(2): 129-132.

Khan, N. U. and Hassan, G. (2011). Genetic effects on morphological and yield traits in cotton (G. hirsutum L.), Spanish Journal of Agricultural Research, 9(2): 460-472.

Khan, N. U., Hassan, G., Kumbhar, M. B., Parveen, A., Aiman, U., Ahmad, W., Shah, S. A. and Ahmad, S. (2007). Gene action of seed traits and its oil content in upland cotton $(G$. hirsutum L.), SABRAO Journal of Breeding \& Genetics, 39: 17-30.

Kiani, G., Nematzadeh, G. A., Kazemitabar, S. K. and Alishah, O. (2007). Combining ability in cotton cultivars for agronomic traits, Iran Journal of Agricultural Biology, 3: 521-522.

Mather, K. and Jinks, J. L. (1982). Biometrical genetics. $3^{\text {rd }}$ Ed. Chapman and Hall Ltd. London, U. K.

Minhas, R., Khan, I. A., Anjam, M. S. and Ali, K. (2008). Genetics of some fiber quality traits among intraspecific crosses of Gossypium hirsutum L., International Journal of Agriculture \& Biology, 10:196-200.

Mohamed, G. I. A., Halem, S. H. M. A. and Ibrahim, E. M. A. (2009). A genetic analysis of yield and its components of Egyptian cotton (G. barbadense L.). Journal of Agriculture \& Environmental Sciences, 5(1): 05-13.

Mukhtar, M. S., Khan, T. M. and Khan, A. S. (2000). Genetic analysis of yield and yield components in various crosses of cotton ( $G$. hirsutum L.), nternational Journal of Agriculture \& Biology, 02(3): 261-263.

Murtaza, M., Qayyum, A., Malik, W. and Noor, E. (2006). Genetic study of yield of seed cotton and plant height in cotton genotypes, nternational Journal of Agriculture \& Biology, 8(5): 630-635.

Soomro, Z. A., Kalwar, M. S., Memon, M. I. and Keerio, M. D. (1995). Genetic analysis of yield and yield components in intra-specific crosses of G. hirsutum L., Pakistan Journal of Botney, 27(2): 431-434.

Steel, R. D., Torrie, J. H. and Deekey, D. A. (1997). Principles and procedures of statistics: A Biometrical Approach. $3^{\text {rd }}$ Ed. McGraw Hill Book Co., New York.

Subhan, M., Qasim, M., Niazi, H. and Khan, M. A. (2002). Assessment of genetic mechanism in some important quantitative parameters in upland cotton (G. hirsutum L.), Asian Journal of Plant Science, 4: 429-431. 